\title{
Children's Right to Participation in Iceland
}

\author{
Elisabet Gísladóttir
}

\section{1 \\ Introduction}

The Icelandic Constitution states that children should by law be guaranteed the protection and care that is necessary for their well-being. ${ }^{1}$ It is clear from the preparatory work on the constitutional provision that it was written with the Convention on the Rights of the Child (CRC) in mind, as it specifically refers to the convention. ${ }^{2}$ The wording of the provision plainly reflects the view, embodied in the $\mathrm{CRC}$, that children are a vulnerable group of people requiring special attention. However, the text does not directly mention what has been considered one of the most revolutionary aspects of the $\mathrm{CRC}$, that is, a child's right to participation. Nevertheless, it can be convincingly argued that the right to participation falls within the ambit of the constitutional provision, as it is inextricably linked to the rights to protection and care.

Since the Constitution does not clearly define children's right to participation, the definition of participation in the CRC is of particular importance in an Icelandic legal context. Children's right to participation is defined by article 12 of the CRC. This article is unique for a human rights treaty in many ways, as it addresses both the legal and social status of children. ${ }^{3}$ Although children lack the full autonomy of adults, article 12 provides all children, capable of forming their own views, the right to express them freely in all matters affecting them and puts the obligation on States to ensure that due weight is given to the views of children in accordance with their age and maturity.

Section 2 of this chapter will begin by looking closer at arguments for including the right to participation as a constitutional right. The main focus of the chapter will then be to provide a brief overview of how the right to participation in article 12 of the CRC and, by extension, the constitutional provision, is reflected in Icelandic law. Section 3 will focus on children and democracy

1 See section 76, subsection 3 of the Constitution of the Republic of Iceland No. 33/1944 (Stjórnarskrá lýðveldsins Íslands).

2 Alpt. 1994-1995, A-deild, pskj. 389 - issue 297, comments with section 14, subsection 3.

3 UN Committee on the Rights of the Child, General Comment No. 12: The Right to be Heard (1 July 2009) CRC/C/GC 12. 
and children's opportunities to participate in public decision-making. Section 4 will then discuss participation in decision-making in individual cases. Questions relating to family life and conflict between parents are undoubtedly among the decisions that affect children and their daily life the most. However, it is also a widespread belief that children need to be shielded from interparental disputes, as they may feel too much pressure to side with one parent or feel responsible for the outcome. Thus, special focus will be given on child participation in decisions about custody, contact and residence in section 5 .

\section{Is the Right to Participation a Constitutional Right?}

Shortly after the CRC was ratified in Iceland in 1992, fundamental changes were made to the human rights chapter of the Icelandic Constitution. The changes, which came into force in 1995, included a new substantive provision about children, making children the only group of individuals to receive specific constitutional protection in Iceland. ${ }^{4}$ This provision can be found in the third subsection of section 76 . It states as follows: 'for children, the law shall guarantee the protection and care which is necessary for their well-being.. ${ }^{5}$ As previously mentioned, the preparatory work on the provision specifically refers to the CRC. It can be concluded from the comments that the constitutional provision was based on article 3 of the then newly ratified CRC. ${ }^{6}$

When the wording of the constitutional provision is compared to the different categories of rights in the CRC, it can be doubted whether the provision protects the right of participation. The CRC is often described as containing three different sub-groups of rights, the so-called 'three Ps'. They are the right to protection, the right to provision and the right to participation. ${ }^{7}$ As mentioned above, the constitutional provision covers the 'protection' and 'care' that is necessary for children's 'well-being'. At first sight, the text of the provision indicates that only the right to protection and provision are protected,

4 See Act No. 97/1995 (Stjórnskipunarlög um breytingu á stjórnarskrá lýðveldisins Íslands, nr. 33/1944, með síðari breytingum).

5 See Hrefna Fridriksdottir, 'Protection of Children's Rights in the Icelandic Constitution' in Trude Haugli and others (eds), Children's Constitutional Rights in the Nordic Countries (Brill 2019) for a more thorough discussion about this Constitutional provision.

6 Alpt. 1994-1995, A-deild, pskj. 389 - issue 297, comments with section 14, subsection 3.

7 See eg Eugeen Verhellen, "The Convention on the Rights of the Child: Reflections from a historical, social policy and educational perspective' in Sara Lembrechts, Ellen Desmet and Didier Reynaert (eds), Routledge International Handbook of Children's Rights Studies (Routledge 2015) 49-5o. 
while the right to participation is left out. The same goes for other constitutional human rights provisions. Even though children's rights are, of course, protected by general human rights principles of the Constitution, e.g. freedom of expression and the right to privacy, no direct reference is made to a child's right to participation. What lies behind this is most probably the early emphasis put on children as a vulnerable group in need of special care and protection from harm and abuse, rather than social actors with the right to be active participants in their own lives, as well as in society. ${ }^{8}$ This emphasis can also be seen in section 33 of the Constitution on democratic participation, which states that persons who are 18 years of age or older on the date of an election have the right to vote.

This different emphasis can also be detected in other Constitutions. In general, Constitutions written before the ratification of the CRC are more likely to represent this so-called welfare perspective, while constitutions adopted or revised after the ratification usually have a more holistic approach to children's rights. ${ }^{9}$ The change to the Icelandic Constitution was, however, made after the CRC had been ratified by Iceland and the preparatory work refers to it. The question, therefore, arises whether the right to participation is covered by the provision and, if not, why Iceland then seems to be an exception from the trend just mentioned. If the right is not protected, it is difficult to answer why the Icelandic Constitution was an exception in this regard, especially considering that one of the main goals of the constitutional revision in 1995 was to modernise the Constitution, in accordance with international human rights obligations. ${ }^{10}$ The office of the Ombudsman for Children in Iceland was established the same year as the revision took place and therefore did not get a real chance to participate in the discussions about this constitutional provision. ${ }^{11}$ In the years following the constitutional revision, the views and attitudes towards children and their rights changed significantly. In that regard, it should be mentioned that in a draft Constitution, made by a Constitutional Council and presented to Parliament in 2011, there was new a provision on children's rights based on the general principles of the CRC, which included a child's right

8 See eg Pórhildur Líndal, Barnasáttmálinn: rit um samning Sameinuðu pjóðanna um réttindi barnsins með vísun i íslenskt lagaumhverfi (UNICE F 2007) 6.

9 The South African Constitution, which came into effect in 1997, is an example of a Constitution that has a more holistic approach to children's rights. Philip Alston, John Tobin and Mac Darrow, Laying the Foundation for Children's Rights (UNICEF Innocenti Research Centre 2005) 21-30.

$10 \quad$ Alpt. 1994-1995, A-deild, pskj. 389 - issue 297, general comments.

11 The Ombudsman for Children Act No. 83/1994 (Lög um umboðsmann barna). 
to participation..$^{12}$ Although the draft was not adopted, this specific provision was generally welcomed and does not appear to have been disputed..$^{13}$

A few arguments support the conclusion that the right to participation falls within the ambit of the constitutional provision. First, even though the text does not explicitly mention the right, it is framed in a wide and open-ended manner using words like 'protection', 'care' and 'well-being'. There is no indication in the provision or its context that the concepts should be construed in a narrow manner. On the contrary, it is an interpretive rule in Iceland that human rights provisions should be, in cases of doubt, construed extensively. ${ }^{14}$ Second, reference is made to article 3 of the $\mathrm{CRC}$, which indicates that the constitutional provision should be interpreted in light of it. Article 3 , as is wellknown, refers to the best interests of the child which is a general principle. In this regard, it can be pointed out that the Committee on the Rights of the Child has consistently stressed that child participation, in accordance with article 12 of the CRC, is an integral part of determining the best interests of a child. ${ }^{15}$ This means that in order to determine what 'protection and care' is needed for children's well-being, it is necessary to consider their views in a meaningful way. On closer inspection, the wording of the constitutional provision mirrors the wording of subsection 2 of article 3 . It indicates that whatever falls within that subsection falls within the ambit of the constitutional provision. This subsection of article 3 has been referred to as a comprehensive 'umbrella provision'. It is considered to constitute 'an important reference point in interpreting the general or overall obligations of governments in the light of the more specific obligations contained in the remaining parts of the Convention'.16 It should be read expansively and in relation to other rights of the Convention, including participation. ${ }^{17}$ It is therefore reasonable to understand the constitutional provision as a broad reference to the $\mathrm{CRC}$ and not just a reference to specific categories of rights.

12 The Constitutional Council, 'The Constitutional Council hands over the bill for a new Constitution' (29 July 2011) <http://www.stjornlagarad.is/english/> accessed 15 August 2018.

13 See eg Alpt. 2011-2012, A-deild, pskj. 3 - issue 3, All comments made about the Constitutional Council's bill for a new Constitution, No. 140/41.

14 Hafsteinn Dan Kristjánsson, Að iðka lögfrææð: Inngangur að hinni lagalegu aðferð (Codex 2015) 159 and 161.

15 UN Committee on the Rights of the Child, General Comment No. 12 (n 1 ) 15.

16 Philip Alston, 'The Legal framework of the Convention on the Rights of the Child' (1992) Bulletin of Human Rights 9 .

17 See eg Rachel Hodgkin and Peter Newell, Implementation Handbookfor the Convention on the Rights of the Child (UNICEF 2007) 40-41. 
Finally, even if it were determined that the constitutional provision was originally not intended to include the right to participation it must be kept in mind that the Constitution has generally been considered a living instrument. ${ }^{18}$ When it comes to human rights provisions, it is considered especially important that the interpretation changes over time, to reflect the changing views in society. ${ }^{19}$ It should also be borne in mind that even if someone does not accept the arguments above, the CRC has been incorporated into Icelandic law. It is therefore at least a legal obligation and an obligation for Iceland within international law.

In light of this, there are convincing arguments for the conclusion that section 76 , subsection 3 , of the Constitution should be interpreted in conformity with article 12 of the $\mathrm{CRC}$, making the right to participation an essential part of the constitutional provision. This means that Icelandic law should guarantee all children capable of forming their own view the right to express those views and have them taken into account in accordance with their age and maturity. The following sections will seek to answer whether or not this right is fully protected in Icelandic law and legal practice.

\section{$3 \quad$ Children and Democracy}

\subsection{The Right to Participation in Icelandic Law}

Article 12 of the CRC has had a vast impact on Icelandic legislation, legal practice and policy since the ratification of the Convention in 1992. Moreover, the CRC was directly incorporated into law in $2013 .{ }^{20}$ Shortly before the CRC became part of the domestic legislation, the four general principles of the CRC were incorporated into the Children Act ${ }^{21}$ with an amending bill that came into force in $2013 .{ }^{22}$ Section 1, subsection 3 of the Act now states that 'Children are entitled to express their opinions on all matters regarding them; fair considerations shall be given to their opinions in accordance with their age and maturity'. Additionally, the right to participation can be found in several different legislations. The right therefore appears to be quite well protected in general legislation.

18 See eg Björg Thorarensen, Stjórnskipunarréttur: Mannréttindi (Codex 2008) 97-99.

19 Róbert R. Spanó, Breytist stjórnarskráin með tímanum (Frettablaðið 2012) 13.

20 Act on the Convention on the Right of the Child No. 19/2013 (Lög um samning Sameinuðu pjóðanna um réttindi barnsins).

21 Children Act No. 76/2003 (Barnalög).

22 Act No. 61/2012 (lög um breytingar á barnalögum, nr. 76/2003, með síðari breytingum (forsjá og umgengni)). 


\subsection{Youth Councils and Other Platforms for Participation in Public Decision-Making}

Children's right to be active participants in a democratic society and influence public decisions has been considered one of the most important aspects of the right to participation, as it recognises children as social actors, instead of just passive recipients of welfare. Along with article 12, articles 13 through 17 make up the so-called democratic or participatory rights of the CRC, which emphasise the fact that children are not only citizens of the future, but citizens in the present, fully capable of making valuable contributions that benefit society. When the right to participation was first introduced in the CRC and Icelandic legislation, it was considered innovative and controversial, and almost impossible to implement. ${ }^{23}$ Since then it has become increasingly recognised that is not only vital for the development of children to give them an opportunity to participate, but also an important step in making the best decision possible and therefore beneficial for society as a whole.

As the CRC is part of Icelandic legislation, children's right to participate in society is formally protected by law. The implementation of this rights has, however, not been very consistent. Some positive steps have been taken, most notably the passing of the Youth Act, ${ }^{24}$ which has a specific provision on youth councils. According to Section 11, subsection 2 of the Act, local authorities should promote the establishment of youth councils. The role of these councils is to advice the local governments on issues relating to children and youth. According to the preparatory works of the Act, the purpose of this provision was to respond to demands for increased democratic participation of young people. It is also mentioned that although the section does not set any age limits, a common age group for these councils is 13 to 18 years of age. After that, young people can participate in democratic elections and directly influence the choice of local representatives. ${ }^{25}$

The wording of previously mentioned provision of the Youth Act has been criticised, as it does not directly require local authorities to establish youth councils. ${ }^{26}$ In 2017 , only 58 per cent of the local governments in Iceland had

23 See eg Umboðsmaður barna, 'Embætti umboðsmanns barna 10 ára - 1995-2005' (The Ombudsman for Children in Iceland 2004) 78-79.

24 Youth Act No. 70/2007 (Eskulýdslög).

25 Alpt. 2006-2007, A-deild, pskj. 46o - issue 409, comments with section 11.

26 Umboðsmaður barna, Report of the Ombudsman for Children in Iceland to the UN Committee on the Rights of the Child (The Ombudsman for Children in Iceland 2010) 5-6. 
an active youth council, but a further 24 per cent said they had intentions of establishing one. ${ }^{27}$ This means that 42 per cent of local governments have no formal platform for democratic participation of children and 18 per cent of them have no plans to change that in the near future. The larger municipalities are more likely to have youth councils than the smaller ones, which means children in rural areas do not have the same opportunity to participate in their local governments as children in larger towns and the capital area. This was addressed in the latest concluding observation of the Committee on the Rights of the Child from 2012, where the Committee expresses its concern that there is no legal requirement for youth councils and that all children may not have equal opportunities when it comes to participation within the municipalities. ${ }^{28}$

Apart from the youth councils, there are very few platforms available for children to exercise their right to participate in public decisions-making. There are some provisions in the school legislation about participation within the school system, for example, about student associations and student representatives in school councils for children aged 6 to $16 .{ }^{29}$ Additionally, there have been several specific measures made to involve children in decision-making and several governmental and non-governmental youth councils are active in public discussion. One example of this is a youth council established in 2018 by the Prime Minister of Iceland about the sustainable development goals. ${ }^{30}$ However, there is currently no formal and constant forum for participation on a national level. This has been criticised, as it means important policy decisions that concern children are most often made without the involvement of children. ${ }^{31}$

\subsection{The Right to Vote?}

In recent years there has been a growing discussion on how to increase children's influence in society. This has led to a proposal about suffrage reform that

27 Umboðsmaður barna, 'Staðan á ungmennaráđum sveitarfélaga' (The Ombudsman for Children in Iceland 2017) <https://barn.is/um-embaettid/verkefni/ungmennaradsveitarfelaga $>$ accessed 19 August 2018.

28 UN Committee on the Rights of the Child, Concluding Observations: Iceland (23 January 2012) $\mathrm{CRC} / \mathrm{C} / \mathrm{ISL} / \mathrm{CO} / 3^{-4}$.

29 See sections 8 and 10 of the Compulsory School Act No. 91/2008 (Lög um grunnskóla).

30 Prime Minister's Office, 'Ungmennaráð Heimsmarkmiða Sameinuðu pjóðanna' (16 January 2018) <https://www.stjornarradid.is/efst-a-baugi/frettir/stok-frett/2018/o1/16/ Ungmennarad-Heimsmarkmida-Sameinudu-thjodanna> accessed 19 August 2018.

31 Umboðsmaður barna, Helstu áhyggjuefni 2017 (The Ombudsman for Children in Iceland 2017) 20. 
would give children from the age of 16 the right to vote in local elections. ${ }^{32}$ The Constitution states that only individuals that have reached the age of 18 have the right to vote in parliamentary and presidential elections. The local voting age is, however, determined by general law, cf. section 2 of the Local Government Elections Act. ${ }^{33}$ Thus, constitutional amendments would have to be made to change the general voting age, while the voting age in local elections can be changed with a simple legal amendment.

The proposal to lower the voting age in local elections has been met with a lot of support, as well as some harsh criticism. Those in favour of the proposal hope that lowering the voting age would increase the interest of government officials in the views and concerns of children and young people. Many have also pointed out that 16-year-old children have reached an age and maturity where they should be able to make informed decisions. ${ }^{34}$ One reason for this is that at the age of 16 children are finishing their compulsory education and, according to the Icelandic national Curriculum Guide for Compulsory Schools, one of the main goals of the school system is to prepare children for active participation in a democratic society. ${ }^{35}$ Furthermore, it has been stressed that lowering the voting age is a step in respecting children's evolving capacities and that providing 16-year-old children with the right to vote is consistent with the fact that they are expected to be able to bear many responsibilities at this age when it comes to medical decisions, decisions about work and education and criminal responsibility, amongst others. ${ }^{36}$

On the other side of the debate, some have emphasised that we should 'let children be children' and protect them from the responsibility of voting. They believe it is difficult enough to be a teenager without the added burden of having to form an opinion on politics. ${ }^{37}$ Furthermore, some people appear to be worried that children will be easily influenced by politicians or that they will anyway just end up voting like their parents. It is interesting to compare this

\footnotetext{
32 Alpt. 2017-2018, A-deild, pskj. 40 - issue 40.

33 Government Elections Act No. 5/1998 (Lög um kosningar til sveitarstjórna).

34 See eg Albt. 2017-2018, A-deild, pskj. 40 - issue 40, Comment from the Union of uppersecondary school student in Iceland, No. 148/223.

35 Ministry of Education, Science and Culture, 'The Icelandic National Curriculum Guide for Compulsory Schools - General Section' (2012) <https://www.government.is/library/ o1-Ministries/Ministry-of-Education/Curriculum/adskr_grsk_ens_2012.pdf> accessed 19 August 2018.

36 See eg Umboðsmaður barna, 'Frumvarp til laga um kosningar til sveitarstjórna, 19o. Mál' (The Ombudsman for Children in Iceland 2017) <https://barn.is/umsagnir/2017/05/ frumvarp-til-laga-um-kosningar-til-sveitarstjorna> accessed 19 August 2018.

See eg Alpt. 2017-2018, B-deild, issue 40, meeting 43 (Inga Sæland).
} 
discussion to the debate about women's suffrage, as it appears that many of the same arguments used against children's right to vote were also used against women's right to vote. ${ }^{38}$

The debate about lowering the voting age in many ways reflects the different attitudes towards children's place in society. On the one hand, you have the view that children should be respected as independent individuals, with evolving capacities to be active participants in society. On the other, you have the emphasis on children as a vulnerable group that needs to be protected and cannot be trusted to make sensible decisions. This highlights the fact that although there has been a significant shift in the view towards children in the recent decades, we still have a long way to go until they will be fully recognised as citizens.

Giving children from the age of 16 the right to vote in local elections would be a positive step towards increasing children's influence in society. But what about the children who would still not have the right to vote? The discussion about children's right to participation in society often leaves out younger children. The efforts that have been made to include children in public discussion, has mostly been aimed at teenagers from the age of 13 to 16, e.g. the youth councils. Even within the school system, it is usually the older children that get a real chance to participate. Although it is consistent with children's evolving capacities to give more weight to the opinions of older children, the Committee on the Rights of the Child has consistently pointed out the importance of younger children being included in decision-making processes in a manner consistent with their age and maturity. ${ }^{39}$ One of the main challenges in Iceland is therefore to provide a platform that will enable all children, including younger children, to actively participate in public decisions that concern them.

\section{Participation in Decision-Making}

The right to participation provides children with the right to exercise some influence over their own lives, making them at least partly autonomous individuals. Nevertheless, it is undisputed that children are not fully autonomous until they reach the age of majority. Thus, parents or other legal guardians of children

38 See eg John Wall, 'Democratising democracy: the road from women's to children's suffrage' (2013) 18:6 The International Journal of Human Rights 646, 653 .

39 See eg UN Committee on the Rights of the Child, General Comment No. 7: Implementing child rights in early childhood (20 September 2006) CRC/C/GC/7; UN Committee on the Rights of the Child, General Comment No. 12 (n 1). 
are legally responsible for their well-being and should provide them with appropriate direction and guidance in a manner consistent with the evolving capacities of the child, cf. article 5 of the CRC. In accordance with the emphasis on a child's evolving capacities, the right to participate in decision-making is often divided into three levels in Icelandic legislation: The right to be heard (samráðsréttur), the right to share in the decision-making (meðákvörðunarréttur) and the right to self-determination (sjálfsákvörðunarréttur).

The right to be heard is protected in several legislations, including the CRC and the previously mentioned section 1 of the Children Act. Furthermore, there are several specific provisions throughout the legislation, for example, when it comes to decisions regarding custody, contact and residence, child protection, education and health. When this right was first introduced into Icelandic legislation, it was often only guaranteed for children from the age of $12 .{ }^{40}$ This has mostly changed, but there are still statutory provisions that only explicitly grant children the right to be heard from the age 12, e.g. the Act on Registered Religious Associations. ${ }^{41}$ Another example is the Personal Names Act, ${ }^{42}$ which provides children with the right to share in the decision-making with regards to the changing of names from the age of 12 but does not specifically refer to the right of younger children to be heard. Although the rights protected in article 12 of the CRC and section 1 of the Children Act should provide younger children with this right, it does not appear to be the case in practice. For example, when the legal guardians of a child under the age of 12 apply for a name change for a child, the National Registry does not provide the child with a chance to participate in the decision. ${ }^{43}$

Although the right to be heard does generally not have an age limit in Icelandic legislation, the right to share in the decision-making and self-determination usually does. One exception is that even though children do not have financial

40 One example of this is section 34, subsection 4 of the older Children Act No. 20/1992, which said all children from the age of 12 had the right to be heard in a custody case, unless it could be harmful for the child or was considered irrelevant for the case.

41 Act on Registered Religious Associations No. 108/1999 (Lög um skráð trúfélög og lífsskoðunarfélög).

42 Personal Names Act No. 45/1996 (Lög um mannanöfn).

43 This has been criticized, see e.g. Umboðsmaður barna, 'Skýrsla umboðsmanns barna 2014' (The Ombudsman for Children in Iceland, 2014) 38-39. A bill on a new Act on Personal Names was presented to Parliament in September 2018. The bill includes a subsection providing all children the right to share in the decision making, in accordance with their age and maturity. It remains to be seen whether this proposal, which includes some fundamental changes to the current legislation on names, will be accepted by Parliament. Alpt. 2018-2019, A-deild, pskj. 9 - issue 9. 
competence, they have the right to control their own earnings and donations, according to the Act on Legal Competence. ${ }^{44}$ The right to share in the decision making is granted to children from the age of 12 in the previously mentioned provision in the Personal Name Act and section 6 of the Adoption Act. ${ }^{45}$ At 15 , children become independent parties in certain child protection cases and get the right to share in the decision making, cf. section 46 , subsection 1 of the Child Protection Act. ${ }^{46}$

Finally, self-determination is most often granted to children from the age of 16. At that age children are entitled to make their own decision about joining or leaving a religious association according to section 8, subsection 1 of the Act on Registered Religious Associations and make their own decisions about health care, cf. section 26 of the Patient's Rights Act. ${ }^{47}$ Additionally, according to section 13 of the Act on Counselling and Education regarding Sex and Childbirth and on Abortion and Sterilisation Procedures, ${ }^{48}$ girls can apply for an abortion without parental knowledge from the age of 16 . When a girl is younger than 16, her parents or legal guardians must make the application with her, unless special circumstances make it inadvisable. ${ }^{49}$

Apart from the previously mentioned legal provisions, Icelandic legislation does not specifically say when children can make their own decisions and when the decision-making power lies with a child's parents. The traditional view is that in absence of a clear law stating otherwise, the parents are the

44 Act on Legal Competence No. 71/1997 (Lögrceðislög).

45 Adoption Act No. 130/1999 (Lög um cettleiðingar).

46 Child Protection Act, No. 8o/2002 (Barnaverndarlög). Being an independent party to a child protection case means a child who has reached the age of 15 must give consent to measures taken by the child protection authorities, unless a formal ruling is made against the will of the child.

47 Patient's Rights Act, No. 74/1997 (Lög um réttindi sjúklinga).

48 Act on Counselling and Education regarding Sex and Childbirth and on Abortion and Sterilisation Procedures, No. 25/1975 (Lög um ráđgjöf og fræðslu varðandi kynlíf og barneignir og um fóstureyðingar og ófrjósemiaðgerðir).

49 A new bill on abortions was presented by the Minister of Health to Parliament in November 2018. If the bill passes, girls of all ages will have the right to self-determination when it comes to the decision on whether or not to have an abortion, see Alpt. 2018-2019, A-deild, pskj. $5^{21}$ - issue 393. This proposal is a response to criticism about the requirement for parental involvement in the decision about abortion for girls under the age of 16, see eg Umboðsmaður barna, 'Skýrsla umboðsmanns barna 2016' (The Ombudsman for Children in Iceland 2016) 25. It has been pointed out the decision on whether or not to terminate a pregnancy is unique, as it burdens not only the girls right to control her own body but could also have a great impact on her future. Thus, it is considered important to respect girls right to privacy and bodily integrity by not requiring parental notification or consent. 
once responsible for making decisions on behalf of a child. In the last few years, however, a greater emphasis has been put on a child's right to autonomy when it comes to certain personal issues, based on their independent right to privacy and participation. Some therefore believe that children should gradually be granted the right to make their own decisions, in accordance with their age and maturity. ${ }^{50}$

The Right to Be Heard in Decisions about Custody, Contact and Residence

\subsection{Decisions about Parental Responsibility}

The growing recognition of children's right to participation has in many ways changed the power relations within families and the views towards parental responsibility. This does not mean that the role of a child's parents is considered any less important than it was decades ago. On the contrary, the CRC puts a strong emphasis on the importance of the family, as is reflected in the introduction to the convention, where it says, 'the family, as the fundamental group of society and the natural environment for the growth and well-being of all its members and particularly children, should be afforded the necessary protection and assistance so that it can fully assume its responsibilities within the community'. However, family has in many ways become a more democratic unit. While parents still have the primary responsibility for the upbringing of their children, they are no longer considered to have the absolute power to make all decisions on their behalf. Rather, they should guide them in decisions-making in a manner consistent with their age and maturity, cf. article 5 of the CRC.

In the last few decades, there has been an increased emphasis on shared parental responsibility. This is evident in article 18(1) of the CRC, which states that efforts should be made to 'ensure recognition of the principle that both parents have common responsibilities for the upbringing and development of the child'. Provisions on parental responsibility can be found in the Children Act, as well as the Child Protection Act and the Act on Legal Competence. If parents are married or have registered their cohabitation in the National Register when a child is born, they share custody of the child. If not, the mother has sole custody of the child, unless the parents make an agreement to share

50 See eg Umboðsmaður barna, Hvenæer ráða börn sjálf (The Ombudsman for Children in Iceland 2015) <https://www.barn.is/frettir/2015/og/hvenaer-rada-boern-sjalf> accessed 19 August 2018. 
custody, cf. section 29 of the Children Act. Consistent with the emphasis put on shared parental responsibility, the main principle is that parents continue to share custody of the child after divorce or separation, unless other arrangements are made. It is also stressed that parents should make a joint decision about residence and contact, cf. section $3^{1}$ of the same Act. The legislation makes it clear that decisions about custody, residence and contact are the responsibility of the parents and not the child. Yet these are decisions that have a great impact on a child's daily life and can potentially influence their future vastly. It is therefore particularly important to respect a child's right to participation before these decisions are made.

\subsection{Participation When Parents Are in Agreement}

Thankfully, most parents are able to co-operate and reach an agreement about custody, residence, and contact. ${ }^{51}$ In accordance with a child's right to participation, section 28, subsection 6 of the Children Act states that 'Parents have an obligation to consult their child, according to the child's age and level of maturity, before taking a final decision on the child's affairs. Greater weight shall be given to the child's point of view as the child grows older and becomes more mature'. Although this means children should in fact have some influence on these decisions, it is difficult to determine whether or not this is the case in practice.

An agreement between parents on the custody and residence of a child does not come into effect until it has been approved by the District Commission$\mathrm{er}^{, 52} \mathrm{cf}$. section 32 , subsection 5 of the Children Act. A decision about contact also needs to be approved for it to be legally enforceable, cf. section 46 , subsection 5 of the same Act. The Commissioner approves an agreement, unless it is not considered consistent with the best interests and needs of the child. Despite this requirement, the general practice appears to be that the Commissioner does not try to establish whether a child has been consulted before the agreement between parents was made. ${ }^{53}$ There is therefore no guarantee that a child's right to participation is respected when these matters are resolved privately.

$5^{1} \quad$ Alpt. 2011-2012, A-deild, pskj. 328 - issue 290.

52 There are nine District Commissioners around Iceland, which are administrative authorities under the Ministry of Justice, cf. Act No 50/2014 (Lög um framkvæmdavald og stjórnsýslu ríkisins í héraði). The District Commissioner are responsible for a number of administrative responsibilities, including decisions about contact.

53 Ásgerður Fanney Bjarnadóttir, Réttur barna til að hafa áhrif (University of Iceland 2017) 96-97. 


\subsection{Disputes about Custody, Contact or Residence}

It is generally believed to be in the best interests of a child when parents are able to resolve their disputes outside of the court system. In line with this, a legislative reform, that came into effect in 2013 , requires parents to attempt to reach an agreement through mediation before requesting a ruling on custody, residence, or contact, cf. section 33 a. of the Children Act. The aim of the mediation is to help parents reach an agreement that is consistent with the best interests of the child. According to the provisions children who have attained sufficient maturity shall be given an opportunity to express their views in the course of the mediation process unless this can be seen as having a damaging effect on the child or as being irrelevant regarding the resolution of the case. In the preparatory works it is clearly stated that in accordance with article 12 of the CRC, the person constructing the mediation should be able to speak to a child without parental consent. ${ }^{54}$ Despite this, there are some examples in practice of children not being allowed to participate during mediation, because it was against the will of one or both parents. 55

When parents are not able to reach an agreement through mediation, they have to request a formal ruling. If the dispute concerns custody or residence, the issue must be resolved in court, cf. section 34 of the Children Act. If parents only disagree about contact, the dispute will be resolved by the District Commissioner, cf. section 47. In both cases, children's right to express their views are protected in section 43 , cf. section 71 of the Children Act. The judge or the District Commissioner can commission an expert to examine the child's point of view. When determining who speaks to the child, it is important to consider what is in their best interests and take into account the age and maturity of the child. Experts with knowledge of child development are often better equipped to speak with younger children, as they have certain techniques to assess to what extent the child is influenced by the parental dispute and evaluate the bond between the child and the parents. ${ }^{56}$

The provision about a child's right to be heard in parental disputes is similar to the previously mentioned provision on mediation. Both provide children 'who have attained sufficient age and maturity' with an opportunity to express their views. ${ }^{57}$ The phrasing of these provisions is more limited than the

54 Alpt. 2011-2012 (n 25).

55 Umboðsmaður barna (n 13) 15 .

56 Hrefna Friðriksdóttir, Handbók: barnalögin nr. 76/2003 með síðari breytingum (Úlfljótur 2013) 164 .

57 Similar wording, where the right to participation is granted to children in accordance with their age and maturity, is common in Icelandic legislation. Another example is section 42, subsection 2 of the Child Protection Act, No. 80/2002. 
wording article 12 of the CRC, which provides all children 'capable of forming his or her own views with the right to express those views freely'. Unlike in Icelandic legislation, the age and maturity of a child does not affect the right to be heard according to the CRC, only the weight given to a child's views. In Icelandic legal practice, there are recent examples of children up to the age of 8 being considered too young to express their opinion, even though it is difficult to argue that most 8-year-olds are not 'capable of forming his or her own views'.58 It is therefore apparent that younger children's rights to participation are not fully respected in practice.

\subsection{Exceptions to the Right to Participation?}

The previously mentioned provisions in the Children Act provide children with an opportunity to express their views when decisions are made about custody residence or contact, 'unless this can be seen as possibly having a damaging effect on the child. This exception was considered important to protect children from having to bear too much responsibility in high-conflict matters. ${ }^{59}$ It implies that being directly involved in a dispute between parents can potentially create a loyalty conflict and be both stressful and harmful for a child's well-being. It is difficult to see that this limitation is in accordance with article 12 of the CRC, considering the emphasis the Committee on the Right of the Child has placed on the complementary roles of Article 3 about the best interests of the child and article $12 .{ }^{60}$ The best interests of the child or the need to protect the child from harm should not be used to 'trump' a child's right to be heard. Rather, efforts need to be made to support the child and provide conditions and information that enable the child to express their views freely and safely. Additionally, the child has a right to participate, not an obligation. ${ }^{61}$ Ultimately, it should be up to the child to determine if they want to participate,

$5^{8} \quad$ Bjarnadóttir (n 26) 99 .

59 Friðriksdóttir (n 31) 163.

6o UN Committee on the Rights of the Child, General Comment No. 12 (n 1); UN Committee on the Rights of the Child, General Comment No. 14: on the right of the child to have his or her best interests taken as a primary consideration (29 May 2013) CRC/C/GC/14 11. Emphasis on the complementary role of these two articles can also be found in Icelandic legal practice. One example of this is the first case where the majority of the Supreme Court of Iceland cited the CRC from 23 November 2011, case no 608/2011. In this case, the Court denied parents request to have their 12-year-old daughter returned to the Philippines, on the grounds that she had adjusted well in Iceland and wanted to stay with her foster parents. Although the Court refers only to article 3 of the CRC, the case demonstrates the complementary roles of the two principles. 
not the adult making the final decision. This exception does not appear to be widely used in practice. ${ }^{62}$

The second limitation found in the previously mentioned provisions is if a child's opinion is considered 'as being irrelevant regarding the resolution of the case'. In the preparatory works for the reform of the Children Act, it is mentioned as an example that it could be meaningless for a child to participate when it is obvious what the decision will be, for example, when one parent is clearly unfit to bear parental responsibility. ${ }^{63}$ Moreover, this exception has been used in practice to limit young children's right to participation. One example of this is a contact case from 2015, where it was considered irrelevant for a 6-year-old child to be heard, as it would most likely not impact the final decision. ${ }^{64}$ Another example of how this exception has been used in practice is a contact case from the same year, where the District Commissioner believed it was irrelevant to speak to a 12-year-old child, as the dispute between the parents was not very deeply rooted. The Ministry of Interior (now Ministry of Justice) overruled this decision. ${ }^{65}$

The CRC does not limit the right to be heard to cases where it is considered relevant for the final decision. In this respect, it is interesting to reflect on the purpose of participation. If the only purpose would be to make 'the right decisions' it could be justifiable to neglect talking to a child when it is self-evident that the child's opinion could in no way impact the decision being made. However, child participation is not only important to determine what decision is in the best interests of a child, it is also meant to empower the child. Having the opportunity to be heard makes children more likely to accept the decision made and encourages children to speak out in the future. Furthermore, it is believed to support a child's development and their sense of autonomy, independence and social competence. ${ }^{66}$ Some might consider it an added burden on children to ask them to express their opinion, if it is already clear what the decision will be. On the other hand, the decision maker could explain in a child friendly manner why a specific decision will most likely be made and still give the child the possibility to comment.

The limitations to the right to participation in the Children Act mean that younger children often do not get heard in cases that concern them. Additionally,

$62 \quad$ Bjarnadóttir (n 26) 116.

63 Friðriksdóttir (n 31) 163.

64 Bjarnadóttir (n 26) 91.

65 Bjarnadóttir (n 26) 102.

66 Geris Lansdown, Can you hear me?: the right of young children to participate in decisions affecting them. Working Paper 36 (Bernard van Leer Foundation 2005) 7-9. 
older children can possibly be excluded from having a say if the decision maker believes it is irrelevant for the final decisions or possibly harmful for their well-being. Despite these limitations, Icelandic decision makers appear to be gradually putting a greater emphasis on a child's right to be heard. In a landmark Supreme Court case from November 2017, ${ }^{67}$ a temporary judgment about a 10-year-old child's legal residence and contact was referred back to the District Court on the basis that the child had not received an opportunity to participate in the decision. In its ruling, the Court refers to article 12 of the CRC and states that it the legal right of children to express their views in all matters that affect them. On the other hand, it also mentions that it can be justifiable in exceptional circumstances to depart from the right to participation and refers to the limitations mentioned in the provisions of the Children Act. The Court therefore appears to have taken a somewhat clear stand on the right to participation, but it also recognises the legitimacy of the limitations to the right. It will be interesting to see if this judgment will influence how the provisions of the Children Act are interpreted in practice, especially when it comes to younger children.

Section 76 , subsection 3 , of the Icelandic Constitution does not explicitly mention the right to participation. Nonetheless, convincing arguments can be given for the conclusion that it falls within the ambit of the provision. Participation should, therefore, be considered an essential part of the constitutional provision about children's right to protection and care. It follows that children have a constitutional right that legislation guarantees their right to participation, as defined by article 12 of the CRC. As the CRC has been directly incorporated into law, Icelandic legislation formally protects children's right to be heard and have their views respected in accordance with their age and maturity. This right does, however, not always fully translate into practice.

When it comes to participation in public decisions, an emphasis has been put on strengthening youth councils and interesting proposals have been put forward about lowering the voting age to 16 in local elections. Such measures would undoubtedly be a positive step towards increasing children's possibility to influence their local communities. Notably absent from this discussion, however, is the participatory rights of younger children, who appear to have very few opportunities to be heard and have an impact on public decisions in

67 Supreme Court of Iceland, case 703/2017. 
Icelandic society. Greater understanding is needed about the fact that child participation is not about giving a select few children the role of representing all other children but providing children of all ages with a real opportunity to be listened to and respected.

Regarding the right of individual children to participate in decisions that affect them, Icelandic legislation reflects the emphasis the CRC puts on the evolving capacities of children. All children formally have the right to be heard, and when they reach a certain age they are granted the right to directly share in the decision making or even the right to self-determination. However, as a legal principle, the right to participation does not always appear to translate into practice. One area where this is evident is decisions about custody, residence and contact. There is no guarantee that children get a real chance to be heard when parents come to an agreement about these issues, as the District Commissioner generally does not give a child the chance to participate before approving a contract between parents. Moreover, provisions in the Children Act both limit the right to be heard based on age and maturity and provide an exception to the right when it is considered harmful to the child or irrelevant for the case. These limitations, especially the way they have been interpreted and applied in practice, do not correspond with the right of participation enshrined in article 12 of $\mathrm{CRC}$, which is arguably protected by the Icelandic Constitution. As when it comes to participation in society, these limitations appear to mostly affect younger children. Icelandic legislation and legal practice, hence, does not fully protect younger children's right to be heard.

It is clear we still have a long way to go before it can be said that a child's right to participation is fully protected in Iceland. However, there has been a considerable shift when it comes to the views and attitudes towards children in the last few years and participation is becoming increasingly recognised as an integral part of determining what is necessary for a child's well-being. The growing awareness of the right to participation will hopefully mean that the provisions limiting the right to participation will be reviewed and the right interpreted in a way consistent with children's fundamental human right to be heard and respected.

\section{References}

Alpt. 1994-1995, A-deild, pskj. 389 - issue 297.

Alpt. 2006-2007, A-deild, pskj. 46o - issue 409.

Alpt. 2011-2012, A-deild, pskj. 328 - issue 290.

Alpt. 2011-2012, A-deild, pskj. 3 - issue 3, All comments made about the Constitutional Council's bill for a new Constitution, No. 140/41. 
Alpt. 2017-2018, A-deild, pskj. 40 - issue 40, Comment from the Union of uppersecondary school student in Iceland, No. 148/223.

Alpt. 2017-2018, B-deild,pskj 40 - issue 40, meeting 43.

Alpt. 2018-2019, A-deild, pskj. 9 - issue 9.

Alpt. 2018-2019, A-deild, pskj. $5^{21}$ - issue 393.

Alston P, 'The Legal framework of the Convention on the Rights of the Child' (1992) Bulletin of Human Rights 9.

Alston P, Tobin J and Darrow M, Laying the Foundation for Children's Rights (UNICEF Innocenti Research Centre 2005).

Bjarnadóttir ÁF, Réttur barna til að hafa áhrif(University of Iceland 2017).

The Constitutional Council, 'The Constitutional Council hands over the bill for a new Constitution' (29 July 2011) < http://www.stjornlagarad.is/english/> accessed15 August 2018.

Friðriksdóttir H, Handbók: barnalögin nr. 76/2003með siðari breytingum (Úlfljótur 2013). Hodgkin R and Newell P, Implementation Handbook for the Convention on the Rights of the Child (UNICEF 2007).

Kristjánsson HD, Að iðka lögfrceði: Inngangur að hinni lagalegu aðferð (Codex 2015).

Lansdown G, Can you hear me?: the right of young children to participate in decisions affecting them. Working Paper 36 (Bernard van Leer Foundation 2005).

Líndal P, Barnasáttmálinn: rit um samning Sameinuðu pjóðanna um réttindi barnsins með vísun í íslenskt lagaumhverfi (UNICEF 2007).

Ministry of Education, Science and Culture, 'The Icelandic National Curriculum Guide for Compulsory Schools - General Section' (2012) <https://www.government.is/library/o1-Ministries/Ministry-of-Education/Curriculum/adskr_grsk_ens_2012.pdf> accessed 19 August 2018.

Prime Minister's Office, 'Ungmennaráđ Heimsmarkmiða Sameinuðu pjóðanna' (16 January 2018) <https://www.stjornarradid.is/efst-a-baugi/frettir/stok-frett/2018/o1/16/ Ungmennarad-Heimsmarkmida-Sameinudu-thjodanna> accessed 19 August 2018.

Spanó RR, Breytist stjórnarskráin með tímanum (Frettablaðið 2012).

Thorarensen B, Stjórnskipunarréttur: Mannréttindi (Codex 2008).

Umboðsmaður barna, 'Embætti umboðsmanns barna 10 ára - 1995-2005' (The Ombudsman for Children in Iceland 2004).

Umboðsmaður barna, Report of the Ombudsman for Children in Iceland to the UN Committee on the Rights of the Child (The Ombudsman for Children in Iceland 2010).

Umboðsmaður barna, 'Skýrsla umboðsmanns barna 2014' (The Ombudsman for Children in Iceland 2014).

Umboðsmaður barna, Hvenæer ráða börn sjálf (The Ombudsman for Children in Iceland, 2 September 2015) <https://www.barn.is/frettir/2015/og/hvenaer-rada-boernsjalf $>$ accessed 19 August 2018.

Umboðsmaður barna, 'Skýrsla umboðsmanns barna 2016' (The Ombudsman for Children in Iceland 2016). 
Umboðsmaður barna, 'Staðan á ungmennaráđum sveitarfélaga' (The Ombudsman for Children in Iceland 2017) <https://barn.is/um-embaettid/verkefni/ungmennaradsveitarfelaga $>$ accessed 19 August 2018.

Umboðsmaður barna, 'Frumvarp til laga um kosningar til sveitarstjórna, 19o. Mál' (The Ombudsman for Children in Iceland 2017) <https://barn.is/umsagnir/2017/05/ frumvarp-til-laga-um-kosningar-til-sveitarstjorna> accessed 19 August 2018.

Umboðsmaður barna, Helstu áhyggjuefni 2017 (The Ombudsman for Children in Iceland 2017).

UN Committee on the Rights of the Child, General Comment No. 7: Implementing child rights in early childhood (20 September 2006) CRC/C/GC/7.

UN Committee on the Rights of the Child, General Comment No. 12: The Right to be Heard (1 July 20o9) CRC/C/GC 12.

UN Committee on the Rights of the Child, Concluding Observations: Iceland (23 January 2012) CRC/C/ISL/CO/3-4.

UN Committee on the Rights of the Child, General Comment No. 14: on the right of the child to have his or her best interests taken as a primary consideration (29 May 2013) $\mathrm{CRC} / \mathrm{C} / \mathrm{GC} / 14$.

Verhellen E, 'The Convention on the Rights of the Child: Reflections from a historical, social policy and educational perspective' in Sara Lembrechts, Ellen Desmet and Didier Reynaert (eds), Routledge International Handbook of Children's Rights Studies (Routledge 2015).

Wall J, 'Democratising democracy: the road from women's to children's suffrage' (2013) 18:6 The International Journal of Human Rights 646. 